Loading

The Journal of the Canadian Game Studies Association

\title{
“The Father of Survival Horror": Shinji Mikami, Procedural Rhetoric, and the Collective/Cultural Memory of the Atomic Bombs
}

\section{Ryan Scheiding}

Volume 12, Number 20, Fall 2019

URI: https://id.erudit.org/iderudit/1065894ar

DOI: https://doi.org/10.7202/1065894ar

See table of contents

Publisher(s)

Canadian Game Studies Association

ISSN

1923-2691 (digital)

Explore this journal

Cite this article

Scheiding, R. (2019). "The Father of Survival Horror": Shinji Mikami, Procedural Rhetoric, and the Collective/Cultural Memory of the Atomic Bombs. Loading, 12(20), 1-14. https://doi.org/10.7202/1065894ar
Article abstract

Video game "authors" use procedural rhetoric to make specific arguments within the narratives of their games. As a result, they, either purposefully or incidentally, contribute to the creation and maintenance of collective/cultural memory. This process can be identified within the directorial works of Shinji Mikami that include a set of similar general themes. Though the settings of these games differ, they include several related plot elements. These include: 1) depictions of physical and emotional trauma, 2) the large-scale destruction of cities, and 3) distrust of those in power. This paper argues that Mikami, through processes of procedural rhetoric/ authorship, can be understood as an "author" of video games that fall into the larger tradition of war and atomic bomb memory in Japan. (Also known as hibakusha (bomb-affected persons) literature). As a result, his games can be understood as a part of Japan's larger collective/cultural memory practices surrounding the atomic bombings of Hiroshima (6 August 1945) and Nagasaki (9 August 1945). In the case of

Mikami, the narratives of his games follow what Akiko Hashimoto labels as the "Long Defeat", in which Japanese collective/cultural memory struggles to cope with the cultural trauma of the Pacific War (1931-1945). To illustrate this argument the paper engages in a close reading of Mikami's Resident Evil, Dino Crisis, Resident Evil 4, Vanquish and The Evil Within and identifies tropes that are common to Japanese war memory and hibakusha literature.
This document is protected by copyright law. Use of the services of Erudit (including reproduction) is subject to its terms and conditions, which can be viewed online. 


\title{
"The Father of Survival Horror": Shinji Mikami, Procedural Rhetoric, and the Collective/Cultural Memory of the Atomic Bombs
}

\author{
Ryan Scheiding \\ Concordia University \\ ryan.scheiding@concordia.ca
}

\begin{abstract}
Video game "authors" use procedural rhetoric (Bogost, 2007) to make specific arguments within the narratives of their games. As a result they - either purposefully or incidentally - contribute to the creation and maintenance of collective/cultural memory. This process can be identified within the directorial works of Shinji Mikami which include a set of similar general themes. Though the settings and genres of these games differ, they include several related plot elements. These include: 1) depictions of physical and emotional trauma; 2) the large-scale destruction of cities; and 3) distrust of those in power. This paper contends that Mikami, through the use of procedural rhetoric, can be understood as an author of video games that fall into the larger tradition of war and atomic bomb memory in Japan. To illustrate this, the paper engages in a discursive cultural reading (Hutchinson, 2019b) of Mikami's Resident Evil, Dino Crisis, Resident Evil 4, Vanquish and The Evil Within to identify themes and plot elements that are common to Japanese war memory and atomic bomb literature. Ultimately, the paper argues that his games can be understood as a part of Japan's ever-evolving collective/cultural memory practices surrounding the atomic bombings of Hiroshima (6 August 1945) and Nagasaki (9 August 1945). The narratives of his games follow what Hashimoto (2015) labels as the "Long Defeat", in which Japanese collective/cultural memory struggles to cope with the cultural trauma of the Pacific War (1931-1945). Furthermore, Mikami's games serve as an example of how Japanese collective/cultural memory continues to incorporate new media and non-hibakusha authors into memory discourses as hibakusha age and, as a result, access to first-hand accounts of the bombs is gradually lost.
\end{abstract}

\section{Author Keywords}

Cultural memory; hibakusha; atomic bomb; Japan; authorship

\section{Introduction}

From August 7-21, 2019 the Hiroshima Peace Memorial Museum held an exhibit with a simple 
title: Atomic Bomb Painting Exhibition. It housed various paintings created by Japanese high school students depicting numerous aspects of the atomic bombs that had been described to them by hibakusha. ${ }^{1}$ English reading visitors were greeted with a plain one-page poster describing the exhibit:

The Hiroshima Peace Memorial Museum has been implementing the Atomic Bomb Drawings Project since 2004. The main objectives of this project are to convey the reality of the damages and suffering caused by the atomic bomb, and to pass down the atomic bomb experience to further generations. After listening to the hibakusha's experiences, the students collected reference materials and began their sketches. They continued revising their drawings based on feedback by the hibakusha until they finally completed their works. Throughout this process, the students wracked their brains in order to draw scenes that were beyond their imaginations. These Atomic Bomb Drawings will be used by the hibakusha when they give their A-bomb testimony so that listeners such as students on school trips can have a better understanding of the experience that is being shared.

Apart from this museum project, our school has been working on A-bomb pictures.

Students, who had no experiences of war, repeat direct personal dialogues with hibakushas and come to experience for themselves what they went through.

Hibakushas are advancing in age and it is an urgent necessity to inherit their experiences. We are trying to make as many pictures as we can.

(Exhibition Poster)

The final lines of this description are particularly important, as Japanese collective/cultural memory of the atomic bombs faces new challenges seven decades after the events in Hiroshima and Nagasaki. Namely, hibakusha are aging and, as a result, access to their firsthand experiences is gradually deteriorating. The Atomic Bomb Painting Exhibition is an early attempt at creating new media pieces to supplement (and eventually replace) the memories of hibakusha. This is an important undertaking, but the question remains: are there other manifestations of these types of collective/cultural memory activities within Japanese culture and media?

This paper examines the directorial works of Shinji Mikami contending that, due to the themes and plot elements found within his video games, they can be read as a contribution to atomic bomb literature and Japanese collective/cultural memory. ${ }^{2}$ Mikami, sometimes referred to as "The father of survival horror" (Reiner, 2014), is a renowned video game director and producer best known for his work on series' such as Resident Evil, Dino Crisis and The Evil Within. This paper argues that Shinji Mikami can be viewed as an author of video games that are part of the larger Japanese atomic bomb literary genre and Japanese collective/cultural memory. This is accomplished in three major parts. The first section examines relevant literature to define authorship in the context of game studies and Mikami's own career. The second section introduces collective/cultural memory theory and atomic bomb literature as a way of highlighting 
important tropes of the genre (i.e. depictions of physical and emotional trauma, the large-scale destruction of cities, and distrust of those in power) and establishing how these are used as the basis of contemporary media. The third section applies this theoretical framework to case studies of Mikami's games, namely Resident Evil (1996), Dino Crisis (1999), Vanquish (2010) and The Evil Within (2014). Ultimately, the paper places Mikami's works within Japanese collective/cultural memory of the atomic bombs, arguing that Mikami and his video games play an important role in introducing atomic bomb memory to video game players and audiences.

\section{Defining Authorship}

The term author and ensuing authorship of a work has become an ambiguous term. This is an issue that has been written about extensively, with reasonable arguments being made for the abolishment of the author function altogether. For example, Roland Barthes (1967), in his influential work The Death of the Author, argues that "[to] give a text an Author is to impose a limit on that text, to furnish it with a final signified, to close the writing" (paragraph 6). He maintains that it is the culmination of capitalist ideology that has attached the greatest importance to the person of the author. As a result, instead of relying upon the importance of the author/author's point of view, a shift should occur in literary critique that privileges the reader and their interpretations over the author. In a similar vein, Michel Foucault (1984) contends that the author is a discursive function that is indicative of power structures within a society. In his words, "[the] author function is therefore characteristic of the mode of existence, circulation, and functioning of certain discourses within a society" (p.108). Thus, within this interpretation, the author is an individual that has been granted power by pre-established discursive practices and structures of power. These influential perspectives force literary scholars to question the value of the author.

While literature and video games are, of course, distinct mediums, they do share important narrative elements. Games, as stories and ludic experiences, engage their players in similar ways to traditional literature. This allows for digital games to be analyzed using literary theory, with some caveats. Indeed, with specific reference to digital games, to ascribe authorship to one individual would also be difficult and problematic if not properly qualified. In particular, claiming that a game has a single author would overlook the work of sometimes hundreds of other individuals involved in the creation, planning, production, marketing and sale of a finished product. The work of these individuals, referred to as immaterial labor and cognitive capitalism by Dyer-Witheford and De Peuter (2009), includes everything from design to writing, to the programming of a game. It should also be noted that these lesser known (at least publicly) workers are responsible for the bulk of work on a game and are most affected by unfair labor practices, such as unpaid overtime, cyclical layoffs and "crunch". In addition to these concerns, the concept of an individual author also overlooks the contributions of players through play and other activities, such as modding. Indeed, these practices are of great importance to gaming and storytelling within the medium.

Reconceptualizing the author within a game studies context has lead Mia Consalvo (2013) to make a case for an idea of corporate authorship. She points out that games are made by many hands numbering from dozens to hundreds, depending on the size of the production. As a result, she argues that instead of attempting to identify individuals that fulfill the author/auteur function, 
it would be more insightful to study corporations that build games. She writes, “... companies work to encode (following [Stuart] Hall) games with particular meanings and conceptual form, and via [this] process they are creating a company brand with a particular identity, history, and context" (p. 325) Using Square Enix as a case study, Consalvo argues that companies choose to author particular types of games while simultaneously making specific decisions about localization and marketing. This theory offers a unique perspective that allows for a type of authorship that falls outside of the traditional single author understanding.

When taken together it is easy to see why authorship, especially in the creation of video games, can be understood outside of the traditional single-author archetype. However, discounting the overall impact of high-ranking or influential employees in the production of video games may be overstepping as well. Acknowledging that many people help in the creation of a game is essential, but it is equally important to recognize that each person involved in a project does not share the same authority or power in the creation of the finished product. In fact, specific employees perform specific roles, and in many cases, a small selection of high-ranking individuals make the decisions that shape the completed game. In other words, they practice authorship over the resources provided to create a specific game. In fact, many high-ranking employees are known for exercising a high amount of creative control over their projects and have been elevated to a type of "auteur" status within the industry. Rachael Hutchinson (2019a) contends that Hideo Kojima is one such example of a video game "auteur" and, as a result, it is necessary and beneficial to consider his personal influence over the games and narratives that he creates. Given Mikami's favorable placement within the current discursive practices around video game authorship that favors well-known and marketable creators, it is reasonable to refer to him as an author of video games. While he may not program a game in its entirety, write the story, create the art assets or market/sell the game, in his role as director he has been given the power to make high-level decisions and shape games as he so chooses (albeit within the constraints of a corporatized model). For the purpose of my analysis, Shinji Mikami will be considered on the level of the "auteur" and thus as an author of the games that he directed because of the creative control that he is believed to exercise. While claims of single authorship may be unfair or overly simplistic when they are applied haphazardly, they still receive discursive institutional support through capitalist regimes, copyright law, and the media that are necessary to understand when discussing the creation of a video game.

If Shinji Mikami can be accepted as an author an important question remains: How does Mikami author a video game? This can be partially described through Ian Bogost's (2007) procedural rhetoric and procedurality. Procedural rhetoric, as described by Bogost, is "a technique for making arguments with computational systems and for unpacking computational arguments others have created" (p. 3). Additionally, Bogost frames procedural rhetoric as a practice of authoring arguments through computational processes. Hutchinson (2019a) provides an example of how this is implemented through an analysis of the role of the bombing of Hiroshima in the works of Hideo Kojima. She notes that Kojima makes use of "a particular vision of history to create, in turn, a particular document, or record of that history" (p. 17). In other words, Kojima practices creative control over his projects and uses procedural rhetoric as a means of putting forth a specific and purposeful argument. I argue that Shinji Mikami practices procedural rhetoric in a similar fashion. Consequently, we can view Shinji Mikami as an author of video games that uses procedural rhetoric to make arguments through his directorial work. Within the 
particular corporate systems that Mikami has been part of, he directs the work of others and shapes these assets into finished products. This activity is not incidental or unplanned. It is a purposeful shaping of design, gameplay and narrative through procedurality to provide a predetermined experience for the player. He is thus a video game author. This terminology is used as a discursive analytical tool. It is not intended to downplay the role of other employees or workers but instead to acknowledge Mikami's position of power within current corporate structures.

Finally, it should be noted that this paper focuses specifically on Mikami precisely because he has been given much creative power in the production of his games while also being celebrated in the media to the point of being referred to as "the father of survival horror" (Reiner, 2014). Yet, the idea that Mikami is an author should be further qualified. Questions of auteurism, beyond what was previously mentioned, or how similar power structures work for other game companies (or other industries) are beyond the intended scope of this paper. Instead, this paper attempts to define a specific type of authorship that Mikami has exercised in his directorial works, to ultimately examine what he has done with his position of power and how this connects to larger systems of Japanese collective/cultural memory, rather than question the discursive role of the author function within the creation of media. Identification of a single author allows for a detailed analysis of how Mikami engages with larger systems of collective/cultural memory.

\section{Collective/Cultural Memory \& Atomic Bomb Literature}

Shinji Mikami's directorial works can be viewed as a part of Japan's atomic bomb and hibakusha literature tradition. Hibakusha is the Japanese term for survivors of the atomic bombings of Hiroshima and Nagasaki in 1945, roughly translating to "bomb-affected persons". In the direct aftermath of the bombings many survivors and journalists/writers who interviewed survivors or visited the cities started to write both fiction and non-fiction works. Many early examples of atomic bomb and hibakusha literature focus on the bombings and their direct aftermath, but in the ensuing decades this expanded into other areas as well, particularly living with radiation sicknesses and the abolition of nuclear arms as a form of promoting peace. There are numerous examples of this literature as it has become a robust genre within Japan and has been partially translated into English (among other languages).

In attempting to display how Mikami interacts with and engages in the genre of atomic bomb and hibakusha literature it is important to acknowledge that he is not a survivor of the bombings of Hiroshima or Nagasaki and therefore is not considered as a hibakusha. Instead, Mikami as an author of atomic bomb literature would be equivalent to Masuji Ibuse or Kenzaburo Oe, whom were also not hibakusha though both wrote influential atomic bomb literature after engaging in extensive research on the bombs and their victims (Ibuse, 1969; Oe, 1996). In terms of personal connection to the bombs it can be argued that Mikami is drawing upon his personal experiences as a youth. A 2013 Eurogamer interview with Mikami reveals that he is perhaps partially influenced by atomic bomb victims when he directs/writes/works on/designs his games. Simon Parkin (2013) notes that in his interview with Mikami he "mentions Hiroshima twice in his recollections about growing up, but, perhaps out of sensitivity for the soil on which we meet, the translator neglects to translate what he says" (paragraph 4). This is unfortunate for the present analysis, as a direct quote about the influence of Hiroshima on Mikami's work by the man 
himself would be immensely valuable. However, Parkin provides further context on the importance of Hiroshima in Mikami's life. He observes that Mikami grew up in Yamaguchi Prefecture which housed numerous victims from Hiroshima in the days directly after the bombing and, as a result, still hosts a large yearly commemoration for the victims of the atomic bombs due to its proximity to Hiroshima (Parkin, 2013). It can be reasoned that Mikami, as a part of growing up in this area, would have been exposed to these ceremonies and developed a historical understanding of the atomic bombs based upon his experiences. While this is an important biographical detail to keep in mind, it is not enough to simply connect or insert Mikami into the hibakusha literature tradition on its own. Instead, the primary connection between atomic bomb literature and Mikami's video games is forged through processes of collective/cultural memory.

The field of collective/cultural memory is rich and varied. It was originally theorized by French Sociologist Maurice Halbwachs in the 1920s. Halbwachs' (1980) work is notable for the way it conceptualizes memory as being based upon group dynamics rather than as an activity or process localized within the individual. In fact, Halbwachs argues that a person is never truly alone, either physically, in thought or in action, and as a result, all memory is influenced by larger structures of power or groups of people. Based on this contention, memory is constructed in the context of the collective rather than the individual: "a person remembers only by situating himself within the viewpoint of one or several groups and one or several currents of collective thought" (p. 33). Thus, memory framed in this way becomes understood as a group activity based upon cultural cues, experiences and power dynamics. An essential part of the creation of collective memory is history as remembered through education, family members and community groups/activities.

Halbwachs' ideas, which he labelled as collective memory, were expanded upon and relabelled as cultural memory by Jan Assmann. Assmann (1995) postulated that "objectivized culture", which he defines as texts, images, rites, buildings, monuments, cities, and landscapes, have a structure of memory which means that these objects help to (often literally) structure how people remember the past. These artifacts of "objectivized culture", then, become the building blocks of cultural memory, which is defined by Assmann (1995) in the following way:

That body of knowledge of reusable texts, images and rituals specific to each society in each epoch, whose 'cultivation' serves to stabilize and convey that society's selfimage. Upon such collective knowledge, for the most part (but not exclusively) of the past, each group bases its awareness of unity and particularity.

(p. 132).

In other words, cultural memory is forged by power structures and popular consensus through physical everyday objects that can be linked to the past. This, for Assmann, is the basis of cultural memory.

Lastly, for the purposes of this paper, it is also important to consider a more recent addition to the field: Astrid Erll's Memory and Culture (2007). Erll capitalizes on the traditions of collective memory in her theorization of cultural memory and media. Her book covers many of the issues within the field of collective/cultural memory, but, in terms of video games and memory, it is her 
conceptions of memory and media that are most important for the present analysis. Erll stresses the importance of media stating that "cultural memory would be inconceivable without the role that media play on both levels- the individual and the collective" (p. 113). Within her understanding of cultural memory, media become the interface connecting the two levels of memory (personal and collective) within the larger system of cultural memory. Erll goes as far as adapting Marshall McLuhan's famous phrase arguing that the "medium is the memory" (pp. 113115). This implies that media are directly connected to memory and are thus instrumental to the creation of cultural memory. Utilizing this framework, this paper argues that Mikami's works are influenced by larger cultural currents such as atomic bomb and hibakusha literature, or memory of the atomic bombs from his personal experiences growing up in Yamaguchi prefecture, and are connected to the collective/cultural memory of the past as an interface of memory. This is seen in his games through the inclusion of depictions of physical and emotional trauma, the large-scale destruction of cities, and distrust of those in power. All of these themes are central to atomic bomb and hibakusha literature.

Akiko Hashimoto's The Long Defeat (2015) is instrumental in pinpointing which system of collective/cultural memory Mikami is connecting to as an interface of cultural memory. Hashimoto (2015) posits that Japan as a political entity and the Japanese people as individuals continue to cope with the trauma of the Pacific War. This has not led to a unified collective memory, but instead has developed into a system where "multiple memories of war and defeat with different moral frames coexist and vie for legitimacy" (p. 4). Hashimoto (2015) identifies three primary trauma narratives that dominate Japanese cultural memory of the war: 1) narratives of fallen heroes; 2) narratives of empathy and identification with tragic (Japanese) victims of defeat; and 3) narratives of Japanese imperialism, invasion and exploitation of China, Korea and Southeast Asia. Within this three-pronged analysis of war memory, Hashimoto places the pacifist narratives of Hiroshima and Nagasaki survivors into the second category. Mikami's works fits into the second type of postwar narrative as they capitalize on established atomic bomb and hibakusha narrative tropes. However, it should be noted that, as a Japanese person, Mikami would be exposed to each of these separate currents of Japanese war memory.

\section{Case Studies}

To best display Mikami's relation to the atomic bomb and hibakusha literature tradition I compare four of Mikami's directorial works, Resident Evil (1996), Dino Crisis (1999), Vanquish (2010), and The Evil Within (2014), with the works of two hibakusha authors, Hayashi Kyoko and Nakazawa Keiji. This comparison is made to elucidate similarities between the works of Mikami and traditional hibakusha authors and, ultimately, to argue that Shinji Mikami's works make use of collective/cultural memory of the atomic bombs to connect to the atomic bomb and hibakusha literature tradition. This analysis needs to be qualified as it is structured by, and based upon, several theoretical assumptions. Firstly, Shinji Mikami is understood as an author of these games based upon the creative control he exercises upon them and the "auteur" status that he is commonly characterized by in games journalism. Secondly, the content of these games is understood to be created through Mikami's use of procedural rhetoric. The gameplay, themes and narrative of these games is not constructed incidentally; instead, they are purposefully designed to make a specific argument or put forward a point of view communicated by Mikami to players. Thirdly, based upon collective/cultural theory, the basis of Mikami's arguments is 
assumed to be grounded in Japanese historical experience that has become the basis of collective/cultural memory. Similarity to the atomic bombings of Hiroshima and Nagasaki within Mikami's games is a non-accidental (though sometimes allegorical) representation deeply influenced by and connected to Japanese collective/cultural memory of the bombs. Based upon these theoretical assumptions, this section examines three specific areas of similarity between atomic bomb and hibakusha literature and Mikami's games: 1) depictions of physical and emotional trauma; 2) the large-scale destruction of cities; and 3) distrust of those in power. These categories are, of course, quite broad and perhaps ever-present in video games and other media. Susan Napier $(1993 ; 2005)$ has observed similar phenomenon is Japanese anime and found that they are not connected to Japanese historical experiences. In particular Napier (1993) argues that Akira is "still attempting to get away from history, or at least to transcend it" (p. 351). However, in understanding Mikami's games through collective/cultural memory theory, this paper argues that the consistency in which references (both direct and indirect) to the atomic bombs appear together within Mikami's games it is more precise to connect them to larger structures of collective/cultural memory such as the atomic bomb and hibakusha literature tradition rather than all depictions of apocalypse or disaster. This follows Hutchinson (2019b) who offers an example of the discursive cultural reading of Japanese games. She argues that games are discursive structures in themselves and that the importance of historical and cultural context within Japanese games should be accounted for in analysis. My analysis follows Hutchinson in the understanding that that "to examine the cultural meaning of a videogame is to analyze the ways in which players might encounter and understand it, which necessitates an understanding of the historical milieu [emphasis added]" (p. 8). The "historical milieu" that Mikami can be most associated with is contemporary atomic bomb collective/cultural memory.

Depictions of both physical and emotional trauma are central to many works of hibakusha literature. This is hardly surprising considering the brutality of the atomic bombs dropped on Hiroshima and Nagasaki and the continued suffering of atomic bomb survivors. ${ }^{3}$ Some of the works of Hayashi Kyoko, a survivor of the Nagasaki bombing, are emblematic of the physical and emotional trauma of the bombs. In Two Grave Markers, Hayashi (1989) tells the story of two teenage girls, Yoko and Wakako, who are sent from their mountain village to work in a factory in "N-City". After surviving the initial blast, the girls manage to escape the factory, but Yoko is badly wounded. Midway through the story Wakako finds maggots growing in Yoko's wounds and flees in fear. As a result, only Wakako makes it back to the village and Yoko eventually dies on the mountainside. The remainder of the story describes, in excruciating detail, Wakako's own death as she succumbs to radiation poisoning. In addition, Wakako must deal with the constant questioning of Yoko's mother, who blames Wakako for her daughter's death. Hayashi's brilliant writing actively conveys the acute physical trauma of the girls, including an intense description of maggots growing in a festering wound. Yet, it is Wakako's emotional suffering and survivor's guilt that weighs heaviest on the reader.

In another Hayashi (1985) short story, The Empty Can, the author is again able to effectively convey both the physical and emotional suffering of atomic bomb victims. The story is told as a reminiscence by a survivor narrator. She weaves together a story about the direct aftermath of the bombs and the present day with a focus on a character named Kinuko. The reader is informed of Kinuko's postwar medical struggles, as she must continually visit a doctor over the course of three decades to have glass shards that were embedded in her back by the atomic bomb removed. 
Yet, it is the titular empty can that has the most lasting impact. Towards the end of the story, the narrator remembers that a mysterious girl who carried around a can was in fact Kinuko. In the days following the bombing Kinuko carried around an empty can to the consternation of her teachers and fellow students. One day, when asked to put away the can by a teacher she bursts into tears. When asked why, Kinuko informs the teacher that the can contains the bones of her parents, which had been extracted by the girl from the ashes of her burned out house. Once again, Hayashi's writing effectively communicates both the physical and emotional suffering of atomic bomb victims through the depiction of death and the psychological/emotional suffering of survivors.

Physical and emotional traumas are central to several of Mikami's directorial works. Physical trauma can be seen quite plainly in Resident Evil (Capcom, 1996). This is mainly conveyed through the appearances of the primary enemies of the game: zombies (both humans and dogs) and hunters (a genetic experiment mixing human DNA with lizards). All of the enemies show signs of physical trauma such as peeling skin, open wounds, and missing limbs. These, coincidently, are reminiscent of atomic bomb victims in the direct aftermath of the bombings (The Committee for the Compilation of Materials on Damage Caused by the Atomic Bombs in Hiroshima and Nagasaki, 1981; Committee of Japanese Citizens to Send Gift Copies of a Photographic \& Pictorial Record of the Atomic Bombing to Our Children, and Fellow Human Beings of the World (Abbr. Hiroshima-Nagasaki Publishing Committee), 1981). Emotional trauma is harder to identify but is still present, both via the tribulations of the characters (who find themselves in harrowing circumstances) and through the experiences of players (mainly because of the genre of the game: survival horror). An important aspect of the emotional trauma commonly found in hibakusha literature is that it is long-term, lasting over decades. This is difficult to include in a survival horror game narrative because the games take place over a much shorter period of time. The player experiences horror through their avatar but they do not get to see the long-term aftermath of that emotionally traumatic experience.

A much more concrete example of physical and emotional trauma in Mikami's games comes from The Evil Within (Tango Gameworks, 2014). The game, which is more focused on psychological horror than Resident Evil's physical horror, creates its horror through the emotional trauma experienced by the characters. This is mainly accomplished through an exploration of the pasts of the player character, Sebastian Castellanos and the main villain, Ruvik. Castellanos, through the use of a pseudo-scientific device created to serve the narrative, is able to travel to a mindscape created by Ruvik and fight the manifestations of the villain's troubled mind. One such monster is named Trauma and is designed to literally be trauma personified. The game describes the creature as "born from Ruvik's concept of death and rebirth" (Tango Gameworks, 2014) and is designed to convey Ruvik's emotional trauma caused by his sister's gruesome death in a fire (which he escaped) through a grotesque physical manifestation. By relegating this event to a time period before the events of the game take place, Ruvik experiences survivor's guilt and PTSD much like many hibakusha. Trauma's name is quite direct, perhaps too much so, but its mangled appearance combined with its narrative importance helps to convey a sense of both physical and emotional trauma that is similar to that experienced by hibakusha and conveyed within atomic bomb and hibakusha literature.

Another concept that is central to atomic bomb and hibakusha literature is the large-scale 
destruction of cities. This is, once again, far from surprising given the uniqueness and unprecedented destruction of Hiroshima and Nagasaki in 1945. While many narratives exist of cities destroyed by natural disasters, fire, or conventional attacks, the atomic bombs were so different in scale and in speed of the devastation that the unique kind of annihilation specific to the two cities has become an important part of atomic bomb collective/cultural memory and the atomic bomb and hibakusha literature tradition.

Depictions of destruction within hibakusha literature are pervasive to the point that they can be found in many examples of the genre. However, Nakazawa Keiji's (2004a, 2004b) manga series Barefoot Gen, can be used as a specific example. Nakazawa's works, which are canonical works in the hibakusha literature tradition, serve as an emblematic example of the genre while, as manga, having the added benefit of visually depicting the destruction. Barefoot Gen tells the story of Gen and his experiences leading up to, during and after the bombing of Hiroshima in 1945. The bulk of the first volume focuses on the period just before the bombing. The reader is introduced to Gen, his family, other secondary characters, and most importantly for this analysis, the city of Hiroshima. It is not until the end of the first volume that the bomb is dropped, and the reader sees the initial flash caused by the bomb, the destruction of buildings, the mushroom cloud, and the spread of fires (Nakazawa, 2004a, pp. 251-271). Seeing the city before this destruction only serves to make its annihilation more powerful and horrific.

Mikami utilizes wide scale destruction within many of his directorial works. For example, it is possible again to turn to Resident Evil. At the end of the first game in the series, the mansion and secret research facilities where the game is set are destroyed by an explosion. Similarly, in Resident Evil 4 (Capcom Production, 2005), the militarized island where the finale of the story occurs is also destroyed by an explosion. ${ }^{4}$ In many ways these events serve as a mirror for the Japanese experience of the Pacific War, where early victories eventually gave way to death via conventional, incendiary and atomic bombing. However, the most apparent parallel to atomic bomb and hibakusha literature comes from Mikami's 2010 game Vanquish (Platinum Games, 2010). Set in the near future, the game opens when a rogue Russian leader, Victor Zaitsev, uses a captured space laser to annihilate the city of San Francisco. Of particular interest is the way that the attack unfolds. There is a large flash and resulting cloud as the laser beam hits the ground in a grove of trees. The resulting shockwave pulsates out as the viewer watches the final tragic moments of the city and its inhabitants. The attack mimics some of the more iconic aspects of the atomic bombings and, when examined through the lens of collective/cultural memory theory, solidifies Mikami's connection to atomic bomb and hibakusha literature.

Finally, a general distrust of those in power is an important aspect of atomic bomb and hibakusha literature that can also be found in the works of Shinji Mikami. In terms of hibakusha literature, the distrust of power can be directed towards the American government/military/polity that dropped the bombs, the Japanese government/military/polity that led Japan into a foolish and costly war, or some combination of the two. For example, Hayashi's (2010) memoir From Trinity to Trinity, describes her trip to the Trinity atomic bomb test site in New Mexico. A major part of Hayashi's narrative is focused on American power and memory and the author's personal refutation of that narrative:

I had had enough of the atomic bomb and Bockscar. Dr. Oppenheimer on the screen, 
Dr. Einstein whose mop head was on souvenir wine labels, and soldiers who were leaving with atomic bombs on board are all heroes. I understand winners create a proud history. Nevertheless, I found myself examining, arguing against, and denying these heroes one by one.

Alternatively, Nakazawa (2004a, 2004b) shows disdain for the Japanese military through the character Hanada, a volunteer pilot who hangs himself due to extreme bullying by his commanding officer. Tragically, the leaders decide to cover this up and say he died heroically in battle, a lie which Hanada's parents are so proud of they chastise his compatriots when they are told the truth. Hayashi and Nakazawa display a general disdain for the irresponsible use of power, even though they target different power structures.

The misuse of power by those in positions of power plays a major part in Mikami's narratives. Once again, this can be found in the Resident Evil series where, seemingly, all those in power use it irresponsibly. In Resident Evil (Capcom, 1996) the powerful Umbrella Corporation makes bioorganic weapons in a quest for profit at a cost of hundreds (and in the sequels hundreds of thousands) of civilian lives. Additionally, one of their co-conspirators, Albert Wesker, is a highranking member of the Raccoon City Special Tactics and Rescue Squad (STARS). In Resident Evil 4 (Capcom Production, 2005) the main villain, Osmund Saddler, manipulates a small village population by starting a cult and sacrifices them in a failed attempt to expand his own power.

However, the best example of the misuse of power in a Mikami game is found in Dino Crisis (Capcom, 1999). The player controls Regina, a member of the Secret Operation Raid Team (SORT), who is tasked with infiltrating Ibis Island to find the scientist, Dr. Edward Kirk. Kirk, believed to be dead by the United States government, is of great importance because of his research's potential military applications. Regina, and the player, discover that Dr. Kirk has been experimenting with a power source called Third Energy. An experiment attempting to harness Third Energy results in an accident that transports dinosaurs to contemporary Ibis Island. The result, once again, is the widespread loss of human life as the dinosaurs kill all of the employees on Ibis Island because of a senseless pursuit of power. Dr. Kirk can be read as an interesting allegory of Dr. Robert Oppenheimer, the scientist that led the Manhattan Project and the creation of atomic bombs, as both are men of science whose pursuit of higher knowledge ultimately leads to destruction and death. This distrust of power through the mad scientist archetype is hardly unique to Mikami's works, or even video games in general. However, its frequent appearance and importance to the plots of Mikami's directorial works provide another important connection to both the atomic bomb and hibakusha literature traditions.

\section{Conclusion}

An examination of Shinji Mikami's directorial games, when processed through theories of collective/cultural memory theory, reveals many connections to traditional representations of the atomic bombings of Hiroshima and Nagasaki. While it cannot be confirmed that Mikami has personally read atomic bomb and hibakusha literature or what his exact intentions in making his games are, the deep connections that this analysis reveals indicates a relationship and similarity between Mikami's games and the literary genre. As a result, it is reasonable to associate Mikami 
with the genre and larger structures of Japanese collective/cultural memory surrounding the atomic bombings. To understand the importance of this connection beyond game studies, it is necessary to contextualize Mikami's games within these larger structures of Japanese collective/cultural memory. Mikami's games have been released in a period when the hibakusha population has started to dwindle in numbers. A time is quickly approaching when there will be no way to access memory of the atomic bombs directly through those that experienced the bombing firsthand. While organizations, such as the Hiroshima Peace Memorial Museum, have started to enact programs that preserve these memories through the creation of artifacts like paintings, it is fair to ask what the role of popular media is in these efforts. I postulate that Mikami's games are a contribution to the endeavor of preserving atomic bomb memory through the creation of media artifacts.

Thus, this case study represents an attempt to theorize how a specific high-level employee within a corporate structure can be considered an author of video games and both engage with and create collective/cultural memory. This analysis finds Shinji Mikami exercises his influence in order to author video games. This authorship is not rudderless. In fact, Mikami's works fit into the established canon of atomic bomb and hibakusha literature and Japanese collective/cultural memory of the atomic bombs. The result is the creation of a uniquely video game centric form of collective/cultural memory that renders horrific pasts as allegorical playable experiences. This should not be viewed as a trivialization, but rather as an important remediation of the past into a different media form. By rendering these pasts playable, the works of Shinji Mikami represent a new type of media artifact that engages with established collective/cultural memory practices and builds upon them in an attempt to keep a traumatic past visible in the present. 


\section{References}

Assmann, J. (1995). Collective memory and cultural identity. New German Critique, 65, 125133.

Barthes, R. (1967). The death of the author. Aspen, 5-6.

Bogost, I. (2007) Persuasive games: The expressive power of videogames. Cambridge, Massachusetts: MIT Press.

Capcom. (1999). Dino Crisis.

Capcom. (1996). Resident Evil.

Capcom Production. (2005). Resident Evil 4.

Committee of Japanese Citizens to Send Gift Copies of a Photographic \& Pictorial Record of the Atomic Bombing to Our Children, and Fellow Human Beings of the World (Abbr. Hiroshima-Nagasaki Publishing Committee). (1981). Days to remember: An account of the bombings of Hiroshima and Nagasaki. Tokyo: Hiroshima-Nagasaki Publishing Company Heiwa-kaikan.

Consalvo, M. (2013). Dubbing the noise: Square Enix and corporate creation of videogames. In J. Gray \& D. Johnson (Eds.), A companion to media authorship (pp. 324-345). Malden, Massachusetts: Wiley-Blackwell.

Erll, A. (2007). Memory in culture. (S. B. Young, Trans.). New York: Palgrave Macmillan.

Dyer-Witheford, N. \& de Peuter, G. (2009). Games of empire: Global capitalism and video games. Minneapolis: University of Minnesota Press.

Foucault, M. (1984). What is an author? In P. Rabinow (Ed.), The Foucault Reader (pp. 101120). New York: Pantheon Books.

Halbwachs, M. (1980). The collective memory. (F. J. Ditter \& V. Y. Ditter Trans.). New York: Harper \& Row, Publishers, Inc.

Hashimoto A. (2015). The long defeat: Cultural trauma, memory, and identity in Japan. New York: Oxford University Press.

Hayashi K. (1985). The empty can. In K. Oe (Ed.), The crazy iris and other stories of the atomic aftermath (pp. 127-143). New York: Grove Press.

Hayashi K. (1989). Two grave markers. In K. Selden \& M. Selden (Eds.), The atomic bomb: Voices from Hiroshima and Nagasaki (pp. 24-54). Armonk, New York: M. E. Sharpe, Inc.

Hayashi K. (2010). From trinity to trinity. (E. Otake, Trans.). Barrytown, New York: Station Hill Press, Inc.

Hiroshima Municipal Motomachi Senior High School, Course of Creative Exprettion. (2019). Atomic bomb drawings [poster]. Hiroshima: Hiroshima Peace Museum.

Hiroshima Peace Memorial Museum. (2019). Atomic bomb painting exhibition. [Museum Exhibition]. Hiroshima: Author.

Hutchinson, R. (2019a). Fukasaku Kinji and Kojima Hideo replay Hiroshima: Atomic imagery and cross-media memory. Japanese Studies, 39(2), 169-189.

Hutchinson, R. (2019b). Japanese culture through videogames. London and New York: Routledge.

Ibuse M. (1969). Black rain. (J. Bester, Trans.). Tokyo: Kodansha International Ltd.

Nakazawa K. (2004a). Barefoot Gen: A cartoon story of Hiroshima volume one. (Project Gen, Trans.). San Francisco: Last Gasp of San Francisco.

Nakazawa K. (2004b). Barefoot Gen: The day after volume two. (Project Gen, Trans.). San Francisco: Last Gasp of San Francisco. 
Napier, S. (1993) The Japanese imagination of disaster from Godzilla to Akira. The Society for Japanese Studies 19(2), 327-351.

Napier, S. (2005). Anime from Akira to Howl's Moving Castle: Experiencing contemporary Japanese animation. New York: Palgrave Macmillan.

Oe K. (1996). Hiroshima notes. (D. L. Swain \& T. Yonezawa, Trans.). New York: Grove Press. Parkin, S. (2013, July). Meeting Mikami: From the archive: Japan's master of horror on the evil within and the evil without. Eurogamer. Retrieved from http://www.eurogamer.net/articles/2013-07-19-meeting-mikami.

Platinum Games. (2010) Vanquish.

Reiner, R. (2014, September). An interview with Shinji Mikami, the father of survival horror. Game Informer. Retrieved from https://www.gameinformer.com/b/features/archive/2014/09/10/an-interview-with-shinjimikami-the-father-of-survival-horror.aspx

Tango Gameworks. (2014) The Evil Within.

The Committee for the Compilation of Materials on Damage Caused by the Atomic Bombs in Hiroshima and Nagasaki. (1981). Hiroshima and Nagasaki: The physical, medical, and social effects of the atomic bombings. (E. Ishikawa \& D. L. Swain, Trans.). New York: Basic Books, Inc., Publishers.

\footnotetext{
${ }^{1}$ Hibakusha translates to "bomb-affected person" and generally refers to survivors of the atomic bombings of Hiroshima and Nagasaki and can also refer to the children of these victims, especially those that were unborn fetuses at the time of the bombings. There has been some recent debate about whether victims of the Fukushima nuclear disaster can be counted among this group.

${ }^{2}$ The atomic bomb literature tradition in Japan can be split into two separate bodies: works written by non-survivors, such as Ibuse (1969) and Oe (1996), and those written by hibakusha, such as Hayashi $(1985,1989,2010)$ and

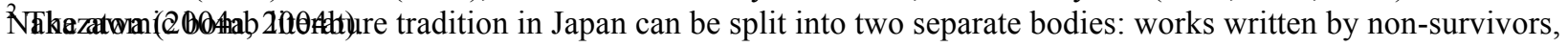
such as Ibuse (1969) and Oe (1996), and those written by hibakusha, such as Hayashi $(1985,1989,2010)$ and Nakazawa (2004a, 2004b).

${ }^{3}$ There are numerous sources that elucidate the effects of the atomic bombs on both cities and human victims. For a full description of the atomic bombs and their aftermath see Hiroshima and Nagasaki: The Physical, Medical, and Social Effects of the Atomic Bombings. For a pictorial record of the bombs see Days to Remember: An Account of the Bombings of Hiroshima and Nagasaki.

${ }^{4}$ Interestingly, the Resident Evil series contains an example of a nuclear missile being used to destroy a city. At the end of Resident Evil 3: Nemesis, Raccoon City is obliterated by the United States government as a way of stopping the spread of the T-Virus. Mikami is listed as a producer on this game rather than the director because he was the directing Dino Crisis at the time of the games production. Whether or not Mikami would have selected such an obvious homage to the bombings of Hiroshima and Nagasaki (rather than the more allegorical representations in Resident Evil and Resident Evil 4) is debateable.
} 